\title{
The Peculiariies of Perception of Family Relations and the Place in the Family by the Child with Attention Deficit and Hyperactivity Disorder
}

\section{Особливості сприйняття сімейних взаємостосунків і свого місця в сім'ї дитиною із синдромом дефіциту уваги та гіперактивності}

\section{Liudmyla Shyriaieva}

Ph.D. in Psychology, Professor, Director of Scientific-Educational Evening Learning Centre, National Pedagogical Dragomanov University, Kyiv (Ukraine)

ORCID ID: https://orcid.org/0000-0002-4797-7340

E-mail: shln_2010@ukr.net

\section{Людмила Ширясва}

Кандидат психологічних наук, професор, директор навчально-наукового Центру вечірнього навчання, Національний педагогічний університет імені М. П. Драгоманова, м. Київ (Україна)

\section{Nataliia Honcharenko}

Postgraduate Student of the Department of Psychology, National Pedagogical Dragomanov University, Counceling Psychologist, Children Clinical Hospital № 4, Kyiv (Ukraine)

ORCID ID: https://orcid.org/0000-0001-5386-3772

E-mail: n.a.honcharenko@gmail.com

\section{Наталія Гончаренко}

Аспірантка кафедри психології, Національний педагогічний університет імені М. П. Драгоманова, практичний психолог,

Address for correspondence, e-mail: kpnu_lab_ps@ukr.net Copyright: (C) Shyriaieva Liudmyla \& Honcharenko Nataliia

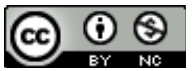
The article is licensed under CC BY-NC 4.0 International (https://creativecommons.org/licenses/by-nc/4.0/)

(C) Shyriaieva Liudmyla, Honcharenko Nataliia

DOI (article): https://doi.org/10.32626/2227-6246.2020-50.328-351 
DOI: https://doi.org/10.32626/2227-6246.2020-50 2020. ВипУСК 50

Дитяча клінічна лікарня № 4 Солом'янського району м. Києва, м. Київ (Україна)

The author's contribution: Shyriaieva L. $-50 \%$, Honcharenko N. $-50 \%$. Авторський внесок: Ширяєва Л. - 50\%, Гончаренко Н. - 50\%.

\section{ABSTRACT}

The aim of the article is to highlight the results of the study conducted among children of primary school age with attention deficit and hyperactivity disorder and the peculiarities of their perception of family relations and their place in the family.

Methods. To achieve this goal and implement the tasks we used the projective technique "Family Drawing". The following criteria for evaluation of drawings are chosen: 1) formal structure of drawing; 2) graphic presentation of family members; 3) the process of drawing. The sample consisted of children aged between 6-10 and their parents with a total of 128 people: 64 children and 64 parents. A structured interview was conducted with the parents.

Results of the research. It has been established that in the perception of the family situation by children with ADHD and their place in the family, there are such general tendencies as anxiety, feelings of inferiority, depression, negative or timid attitude towards one of the parents, negative attitude towards siblings. The following types of distress are common in families of children with ADHD: quarrels between parents, conflicts between parents (or one of them) and a child with $A D H D$, between him / her and siblings, ignoring the child, hypersocialization of the child, hypercontrol, etc.The graphic characteristics of the drawing, which have a symbolic meaning for determining the satisfaction / dissatisfaction of the child's needs, are analyzed quantitatively and qualitatively (with an illustration of examples). It is shown that the drawing reflects two vectors of the child's experience of his / her place in the family: "acceptance» and "rejection». The child's feeling of "rejection" in the family was more common in contrast to the "feeling of acceptance» (71.8\% and $28.1 \%$, respectively). As a way of processing the "feeling of rejection", children prefer to "drive themselves out» rather than the family, which indicates the deprivation of the need for intimacy, belonging.

Conclusion. Family drawings can be used in the diagnosis of children with $A D H D$ to build the following psychocorrectional hypotheses to implement effective psychological care for the child and the family as a whole.

(C) Shyriaieva Liudmyla, Honcharenko Nataliia DOI (article): https://doi.org/10.32626/2227-6246.2020-50.328-351 
DOI: https://doi.org/10.32626/2227-6246.2020-50 2020. випуск 50

Key words: family, interpersonal relationships in the family, ADHD (attention deficit and hyperactivity disorder), projective techniques, technique «Family Drawing", feeling of belonging, feeling of rejection.

\section{Introduction}

Family for the child has been and remains an important centre for the formation of his / her personality both in everyday consciousness and in most psychological theories of development. Despite the differences in the interpretation of the focus and factors of mental development of the child, the scientific opinion is mostly unique in the question of the influence of the family atmosphere and the nature of interaction in it on the formation of the child's personality. If the family is friendly, harmonious, responsible, parents are acceptable to the child, they make balanced and adequate demands on the child, then the child has every chance to develop harmoniously, grow in harmony with himself / herself and the world. Any conflicts in the family, inconsistent disciplinary measures, hostility towards children give rise to, respectively, child's hostility, rejection of oneself and / or others, many unproductive psychological defenses, and so on.

Today, attention deficit and hyperactivity disorder (ADHD) is an officially recognized neuropsychological disorder of a polymorphic nature, caused by the peculiarities of brain function. For a child with attention deficit hyperactivity disorder, family can both compensate for developmental disorders and become a centre for its optimization with a prognosis for successful social adaptation of the child (under appropriate design conditions), and cause many serious secondary consequences, comorbid disorders, personal and social problems in adulthood (Semakova \& Makarova, 2007; Johnston \& Mash, 2001). Therefore, the study of the peculiarities of the child's perception of family relations and his / her place in the family is a necessary link in providing psychological assistance to a child with ADHD and his / her parents.

C Shyriaieva Liudmyla, Honcharenko Nataliia

DOI (article): https://doi.org/10.32626/2227-6246.2020-50.328-351 
The study of the perception of peculiarities of intrafamily relations by children with certain developmental problems has received enough attention from researchers who aimed to involve the family in psycho-correctional and developmental activities to help the child. The existence of the correlation between ADHD and the family system is indicated by most researchers on this issue (Briazgunov \& Kasatikova, 2001; Semakova \& Makarova, 2007; Politics, 2006; Romanchuk, 2015; Sukovskyi, 2008; Sukhina, 2018; Barkley, 1998; Johnston, Godinez, Willcutt et al, 2015; Johnston \& Mash, 2001). According to the current data, unfavorable conditions of the prognosis for the development of a child with ADHD are such disorders of family and family functioning as: low social standard of living, high proneness to conflict in the family, manifestations of aggression between parents and children, hostility between siblings, ignoring the child, a high level of parental requirements which are incompatible with the capabilities of the child, etc.

The aim of this article is to highlight the results of a study of the characteristics of the perception of interpersonal relations in the family and the place in it by the child with attention deficit and hyperactivity disorder, using the projective technique «Family Drawing» .

The results described in the article are a fragment of more detailed study of the system of child-parent relations, which are an important factor in the psychological well-being of both children with ADHD and their parents.

\section{The tasks of the article}

To achieve the goal, the tasks of the article were as follows: substantiation of the projective technique in the implementation of the study and, in particular, the technique «Family Drawing»; description of the research procedure, criteria for evaluation of drawings and the process of their implementa-

(C) Shyriaieva Liudmyla, Honcharenko Nataliia DOI (article): https://doi.org/10.32626/2227-6246.2020-50.328-351 
DOI: https://doi.org/10.32626/2227-6246.2020-50 2020. випуск 50

tion; analysis of the results of an empirical study of the nature of the perception of children of primary school age with ADHD interpersonal relations in the family and their place in it; illustration of the results by concrete examples; conclusions about the obtained results.

\section{Methods and techniques of the research}

The study of the peculiarities of the child's perception of interpersonal relationships in the family was conducted using the technique «Family Drawing» during individual receptions of parents and children in the psychological service of the Children Hospital №4 in Kyiv, where they sought a professional help. To assess the family situation comprehensively, the children's drawing data were compared with the results of observations and interviews with children during the drawing and interviewing parents.

\section{Results and discussions}

In the study of the child's perception of the system of family relations, projective methods, in particular, drawing tests, became widespread in psychological practice. The diagnostic value of children's drawings has been repeatedly confirmed by experts from around the world (Burns \& Kaufman, 1972; Corman, 1964; DiLeo, 1973; Harris, 1963, Krisch, 2019; Bodalev, Stolin \& Avanesov, 2000; Mukhina, 1981; Homentauskas, 1984, etc.). The popularity of drawing techniques is due to several reasons: 1 ) the process of drawing (it is close to the game, and it allows you to establish emotional contact with the child quickly, to relieve his / her tension, if there is any); 2) the availability of tools and convenience of the procedure (a sheet of paper, pencils, eraser; the ability of the psychologist to observe the course and changes in the emotional states of the child under study); 3) many times confirmed facts of diagnostic value of how the child perceives himself / herself and (C) Shyriaieva Liudmyla, Honcharenko Nataliia

DOI (article): https://doi.org/10.32626/2227-6246.2020-50.328-351 
other family members, what feelings he / she experiences in the family; 4) psychotherapeutic effect of the drawing process, etc.

The younger a child is, the more imagery, expression and originality are in the way he / she draws the world (DiLeo, 2012). It has been established that drawing allows a child to convey those feelings that he / she is not able to formulate yet. Ukrainian psychologists recognize that the child's drawing can be considered as a language that has greater communicative potential than oral and graphic ones (Belyauskaite, 2003; Wenger, 2003; Mukhina, 1981; Homentauskas, 1993, etc.).

The technique «Family Drawing», which was used by us in the study, is an informative means of learning the child's personality, because it reflects how the child perceives himself / herself and other family members, what feelings he / she experiences in the family. The technique exists in various modifications and is used primarily to study the structure of the family and the characteristics of the relationship between family members in the perception of the child. It is believed that it is better to use the "Family Drawing" between 6-10, when the graphic expression is more or less formed, but it still remains quite individual and relatively free from cultural pressure.

The sample of this study consisted of children aged betwen 6-10 and their parents with a total of 128 people: 64 children and 64 parents (one of the child's parents participated in the survey). Among the children there are 18 girls and 46 boys. All children lived with their parents or one of them at the time of diagnosis. Children in this sample did not have such comorbid disorders as mental retardation, epilepsy, visual and hearing impairment. There were found enuresis, dyslexia, dysgraphia, tics in the anamnesis among the concomitant ADHD disorders.

Drawing and communication with children took place with the consent of the parents alone with the child or in the presence of one of the parents, who was sitting nearby. The children were diagnosed with ADHD by child psychiatrists and neuro-

(C) Shyriaieva Liudmyla, Honcharenko Nataliia DOI (article): https://doi.org/10.32626/2227-6246.2020-50.328-351 
DOI: https://doi.org/10.32626/2227-6246.2020-50 2020. випуск 50

logists. The diagnostic procedure with children was carried out according to the standard scheme: after establishing contact with the child and his / her consent to the proposal to «draw», the child was given a sheet of white paper $(21 \times 29 \mathrm{~cm})$, graphite and colored pencils, an eraser and instructions: «Draw, please, your family». We have avoided the explainations what the word «family» means, so as not to lose the essence of the study. If a child asked who to draw, we simply repeated the instructions. The time to complete the task was not limited, but on average it lasted no more than 20 minutes: it is difficult for children with ADHD to keep a long attention when performing any activity. After the drawing, a short conversation was held, in which, in addition to individual questions for each child, the following were mandatory: "Who is drawn here?», «What do they do?», "Which of them is the happiest / most unhappy?», «Why?» etc. Structured interviews were conducted with parents to determine the nature of the family microclimate. These data were then compared with the analysis of children's drawings and conversations with them.

One way to interpret a child's family drawing is a three-level scheme, according to which the drawing is analyzed according to the following criteria: 1) the formal structure of the drawing; family composition; the presence of «extra» - not family members; the presence of animals and other objects, location of figures in the drawing, the presence of distances, etc.); 2) graphic presentation of family members (nature of lines, hatching, proportions of figures, presence of details of a body, decorativeness, use of colors); 3) the process of drawing (the child's behavior, his / her expression, the pace of work, the sequence of drawing figures and details, pauses, erasures) (Belyauskaite, 2003; Bodalev, Stolin, Avanesov, 2000; Homentauskas, 1985). We have used the above mentioned technology to analyze children's drawings. The conducted content analysis of the presence of the above-mentioned features in children's C Shyriaieva Liudmyla, Honcharenko Nataliia

DOI (article): https://doi.org/10.32626/2227-6246.2020-50.328-351 
DOI: https://doi.org/10.32626/2227-6246.2020-50

2020. ВипУСК 50

drawings allowed to establish a number of dominant and weakly expressed ones (Table 1).

Table 1

Quantitative indicators of interpretive features in the family drawings of children with ADHD

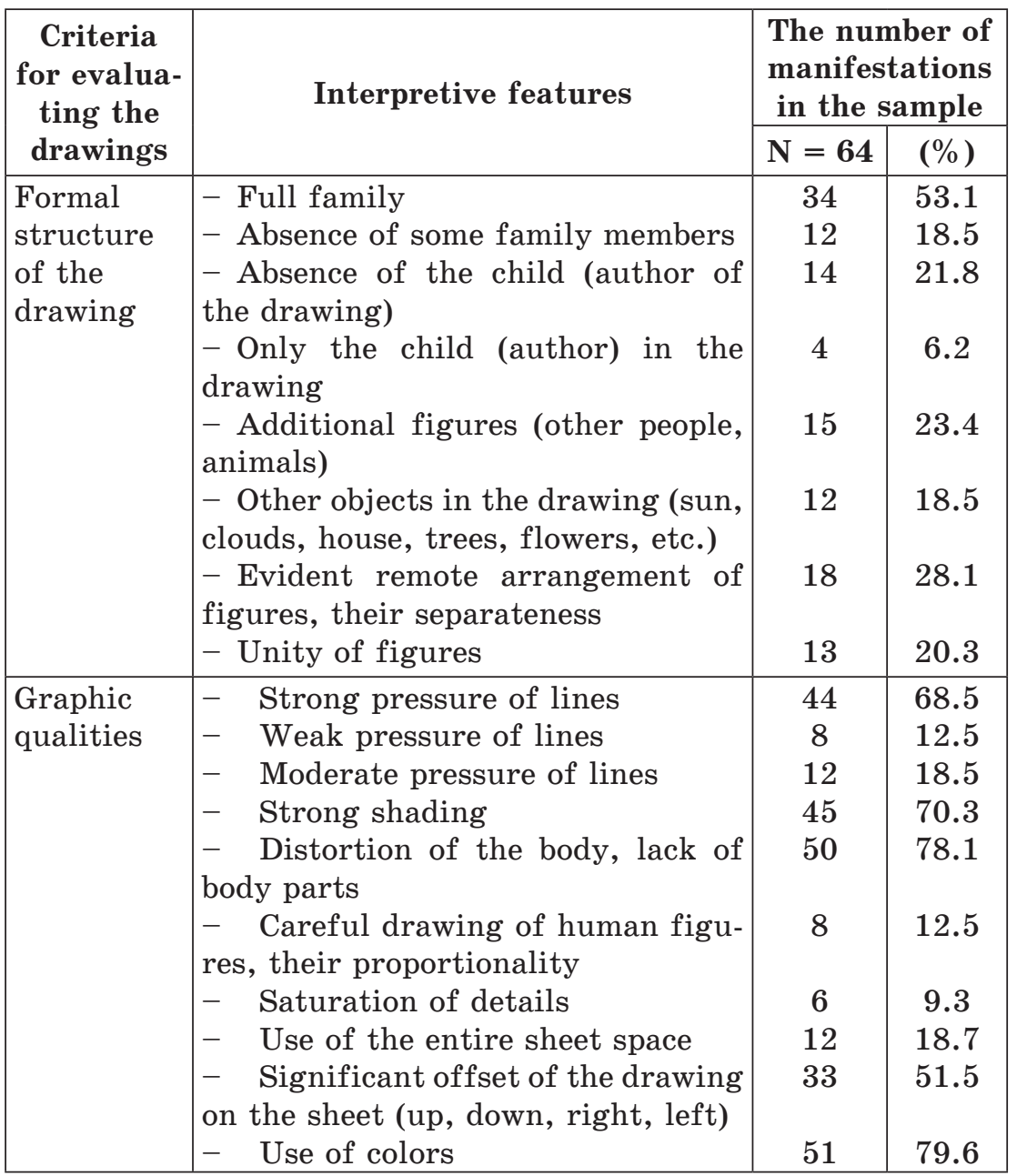

(C) Shyriaieva Liudmyla, Honcharenko Nataliia DOI (article): https://doi.org/10.32626/2227-6246.2020-50.328-351 
DOI: https://doi.org/10.32626/2227-6246.2020-50

\begin{tabular}{|l|l|c|c|}
\hline The & - Fast (impulsive) completion of & 44 & 68.7 \\
drawing & the task (up to 15 minutes) & & \\
process & - Poor planning & 19 & 29.6 \\
& - Erasing & 34 & 10.9 \\
& - Many questions & 53.1 \\
& $-\quad$ Looking at parents (in their & 41 & 64.0 \\
\hline & presence) or looking at a psychologist & & \\
\hline
\end{tabular}

Thus, the following features dominate in the drawings of the family of children with ADHD: the full composition of the family (53.1\%), the strong pressure of the lines $(68.5 \%)$; strong shading (70.3\%); body curvature, disproportion, absence of arms, legs, mouth, nose, ears, hair (78.1\%); significant offset of the drawing on the sheet (up, down, right, left) $(51.5 \%)$; use of colored pencils (79.6\%); fast (impulsive) completion of work (up to 15 minutes) (68.7\%); many questions of the child to the psychologist during the drawing $(53,1 \%)$; looking at the parents (in their presence) or looking at the psychologist (64\%). Also, it has been noticed a low representation of such interpretive features as: only the child (author) in the drawing $(6.2 \%)$, saturation of human figures with details $(9.3 \%)$, erasure of the drawn $(10.9 \%)$; weak pressure of lines $(12.5 \%)$, careful drawing of human figures, their proportionality $(12.5 \%)$.

The characteristic for the children with ADHD is fast impulsive drawing (up to 15 minutes), not caring about its quality and accuracy - they can simply cross out what is not desirable, draw on top of what is drawn, without erasing with an eraser, including drawing in one color on top of another. They are characterized by poor planning (drawing without thinking about where to start, may start drawing from another large object (such as a house), not focusing on whether the family will fit in the available space of the sheet of paper; uncontrolled, chaotic activities (change posture during drawing, distracted, ask a lot of questions that do not relate to the subject (c) Shyriaieva Liudmyla, Honcharenko Nataliia

DOI (article): https://doi.org/10.32626/2227-6246.2020-50.328-351 
of drawing), poor coordination (lines go beyond the contours, parts of the body are poorly connected, can «run into» each other). During the conversation they can impulsively start to finish the details that are missing in the drawing, and often too demonstratively (for example, big ears in the whole family, everyone's hair is the same with strong pressure, etc.). Demonstrative behavior during conversation is common among boys with ADHD of predominantly hyperactive-impulsive and complex subtypes, but this audacity often looks like a defensive response which they showed to anticipate the threat to their «ego»; sometimes a neutral question could provoke a protest.

Children with ADHD do not have trifles in drawing: details, decor, if any, are scarce. Rough, inflexible line of drawing prevails, inorganicity of human figures - their awkwardness, disproportion, lack of body parts (arms, legs or feet, parts of face and head - nose, mouth, ears, hair), fuzzy clothes, lack of shoes. All this may indicate an underdevelopment, break of the concept of the body in a child, which has repeatedly been the subject of research by Western scientists, such as DiLeo (2012), and others. D. Dileo explains such distortions by both internal neurological dysfunctions and external factors that adversely affect the emotional life of the child. These facts are partially confirmed in the research of children with ADHD by O. Polityka (Polityka, 2005).

There are lots of more colorful drawings in children's works than achromatic ones. We have noticed that the use of violet color (or its lighter shade - lilac) is widespread among children with $\mathrm{ADHD}$, which is often associated in psychology not only with mysticism, but also with psychological immaturity, infantilism, nervous system instability, diseases associated with hormonal imbalances, etc. (Serov, 2019). This fact seems quite natural for the psychophysiology of $\mathrm{ADHD}$, which, however, needs more detailed examination, because in other studies that used projective tests in the assessment of children, such observations on the preference of purple color were

(C) Shyriaieva Liudmyla, Honcharenko Nataliia DOI (article): https://doi.org/10.32626/2227-6246.2020-50.328-351 
not noticed (for example, in the work of M. Fedorenko, 2015, where the Luscher test was used in the diagnosis of preschool children with ADHD and mental retardation). An obvious explanation may be the difference in the samples: children of preschool and primary school age, with mental retardation and without this disorder.

The presence of the full family, as it turned out in the comprehensive interpretation of each case, is not a sufficient argument in favor of the child's perception of self and interpersonal relationships in the family, without taking into account the whole composition (structure) of drawing, the nature of drawing figures, their location, use of colors, pauses, sequence of appearance of figures in the picture, answers to the above questions to the child, etc. Therefore, from a diagnostic point of view, it is more informative to analyze children's drawings individually in conjunction with the results of parental interviews and conversations with the child about what he or she portrays.

In illustrating the examples and determining the nature of the child's perception of his / her place in the family, we used psychological dimensions, which, in our opinion, were substantiated for the method of «Family Drawing» by G. Homentauskas. In particular, he identified two such dimensions: 1) «sense of rejection» and «sense of belonging»; 2) «symbolic expulsion of the family» and the symbolic "expulsion of oneself» as graphic ways for a child to "process» feelings of rejection. Let's look at examples of how they are reflected in the drawings of children of primary school age with ADHD.

Negative experience of the child related to the family, dissatisfaction with the family situation and «feelings of rejection» can be seen in the process of drawing at the beginning: refusal to perform the task ( $\mathrm{I}$ do not want to draw»), distraction of the psychologist ("Where do you get such beads?», "Can I look at those toys?»), partial sabotage of the task (they start drawing, but something else, but not the family).

(C) Shyriaieva Liudmyla, Honcharenko Nataliia

DOI (article): https://doi.org/10.32626/2227-6246.2020-50.328-351 
In the formal structure of the drawing the emotional distress of children with ADHD is manifested in the change of the family structure: the exclusion of oneself, one of the parents, siblings, or the inclusion in the family of people who are not directly related to it. Graphically, "feelings of rejection", anxiety, stress can be signaled by the image of clouds, strong hatching, redrawing of an already drawn family member, the use of black with intense pressure, which were confirmed in subsequent discussions of the drawings with the child.

Lack of emotional communication in the family, the contradiction of educational techniques are evidenced by the large number of different objects in the picture, images of other people, non-family members, animals. For example, Fig. 1, made by a boy of 8 years, shows two figures of the girls «Alina» and "Masha», who are his classmates. The internal conflict of the author in relation to the image is conveyed by the contradictions between the graphic presentation of the figures in the drawing (limbs with outstretched fingers, dark hatching of clothes and faces - aggressive symbolism) and their names written in pink hearts under the figures. As the boy himself explained, these girls constantly tease him, but they are his friends. They communicate with him during breaks that is essential for a child with ADHD who may have problems with peers. He refused to comment on the refusal to draw a family (parents are divorced, the boy is being raised by his mother and grandmother), limiting himself to the phrase «let it be so" . Despite the refusal to draw a family, it can be assumed that in this case there is a transfer from parental figures to peers, due to internal conflict. The absence of the boy in the picture indicates that he has a feeling of rejection both in the family and at school. In the interview, the mother confirmed her son's conflicts at school, which she had heard about from teachers many times, but, in her words, "she stopped paying attention to it because she was tired and used to it». He often takes the position of either strict measures of control and punishment,

(C) Shyriaieva Liudmyla, Honcharenko Nataliia DOI (article): https://doi.org/10.32626/2227-6246.2020-50.328-351 
DOI: https://doi.org/10.32626/2227-6246.2020-50

or «falling in love» with her mother (the boy's grandmother), when the actions of punishment cause a complex of guilt.

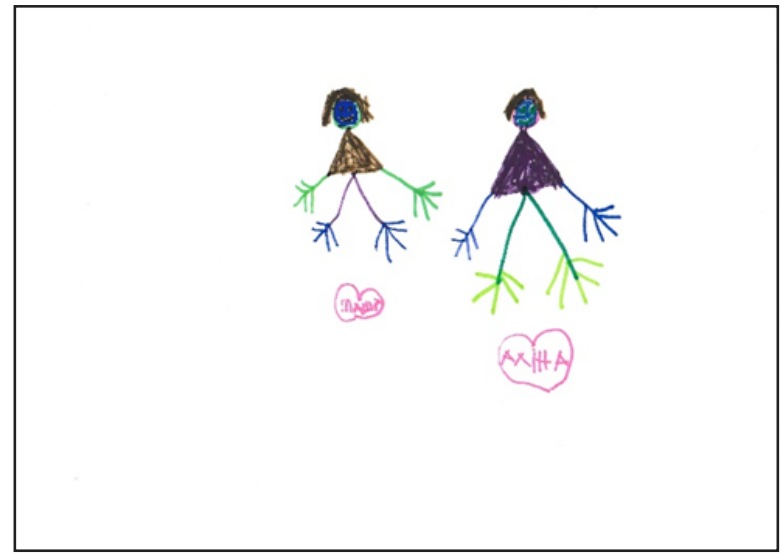

Fig. 1. Drawing of an 8-year-old boy

The child's feeling of inferiority can be reproduced in the picture by a disproportionately small figure of the author himself; the location of the figure at the bottom of the sheet; isolating the child's figure from other family members; the absence of the author in the drawing, etc. Children who grow up in a family with a feeling of inferiority often show a characteristic stereotype - shame. They may refuse to draw, often look at their parents if they are present at the diagnosis, try to finish work faster. Most often, in such cases, they either «forget» or "do not want» to draw themselves, and according to G. Homentauskas (Homentauskas, 1984) it is a way for a child to process the feeling of rejection through symbolic expulsion from the family.

Fig. 2 shows three figures: a mother - in man's clothing, a father, a younger brother. The father covers his younger son's face with his palm. The author himself (an 8-year-old boy) is not present in the drawing ( «I don't want to draw myself»). The boy is shy, very slow. ADHD (mostly of an inattentive C Shyriaieva Liudmyla, Honcharenko Nataliia

DOI (article): https://doi.org/10.32626/2227-6246.2020-50.328-351 
subtype) was detected when he went to school. The reason for going to the doctor is inattention, low school performance, reading problems, dysgraphia. According to the mother, the situation in the family is good. However, the child clearly feels emotional deprivation, his rejection, uselessness. The younger child is healthy, and with his birth the parents switched more to his upbringing. Unconsciously, they show more love and affection for him. The eldest son is also given attention, but mostly in helping with learning. During the conversation the mother admitted that the eldest son in the family gets less friendliness, tenderness, hugs, etc. Graphically, the author's jealousy of his younger brother is reproduced by covering his face with his father's hand. Feelings of inferiority are expressed in the displacement of the drawing in the lower corner of the sheet. Feelings of rejection are psychologically transformed by the child through the symbolic expulsion of himself from the family.

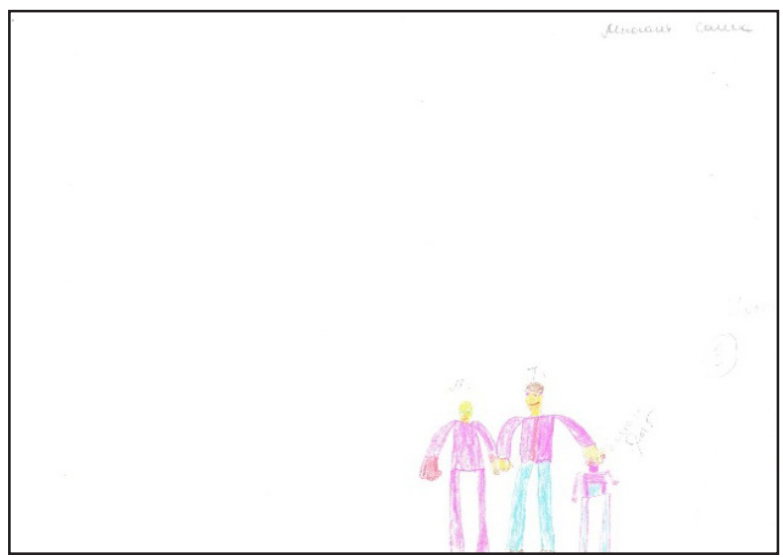

Fig. 2. Drawing of an 8-year-old boy

The presence of anxiety can be predicted, if the drawing is expressed with hatching, strong pressure of lines, a clear line of the base, the child erases details, crosses out, circles

(C) Shyriaieva Liudmyla, Honcharenko Nataliia DOI (article): https://doi.org/10.32626/2227-6246.2020-50.328-351 
DOI: https://doi.org/10.32626/2227-6246.2020-50 2020. випуск 50 them, does not finish details, draws animals and so on. In some cases, even with the overall positive image of the whole child, the figures in it, the child's anxiety can be a strong shading of certain parts of the body of other family members (where the source of the threat is felt), or the child himself / herself. In conversation children with an anxious symptom pause think long about the answer, as if trying not to «make a mistake» and answer «right», have difficulty explaining why someone is happy and someone is not ( $\mathrm{I}$ do not know», "It seems to me...» etc.). Another characteristic behavior of children with anxiety syndrome is protective and aggressive behavior as a discharge of tension.

For example, in Fig. 3 a 9-year-old girl gets anxiety from their parents, especially the father (his figure is distorted, marked by strong black hatching, at a distance from the child, where the barrier between them is the mother). The figures are close together, but they all lack hands as a marker of impaired communication in the family. When asked "Who is the happiest in the family?», the girl called herself, because others, in her words, «feel worse». During her parents' quarrels, she gets angry with them, and when asked what she would like in such situations, the girl answered: "no arguing and mom's hug». However, the mother goes away after the quarrel, leaving her alone.

After the conversation with the mother, it became clear that the family is really in a difficult period: the father has lost his job, there are constant quarrels and scandals in the house. ADHD in a child is complex: she is hyperactive, needs a lot of attention, the school notes her proneness to conflict, arrogance, unsociability. Her high energy is demonstratively expressed in the hot yellow color with which she adorned herself in a dress. The child often reacts with anger and disobedience hiding her anxiety states in such a way. 


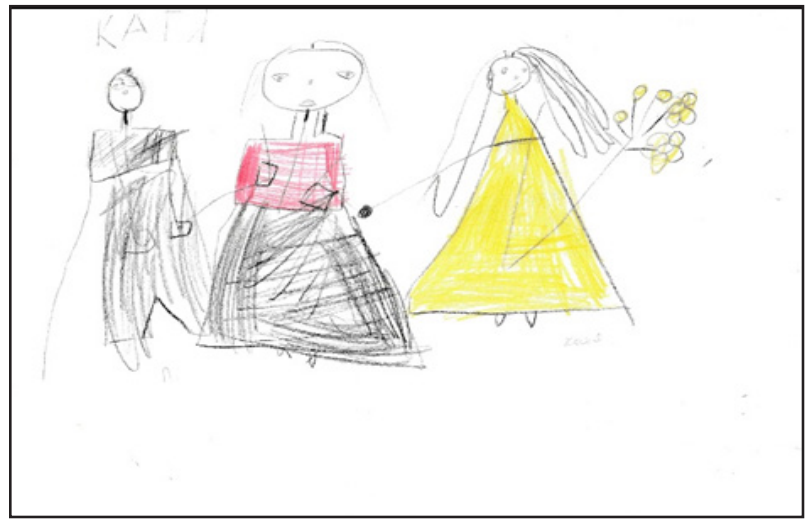

Fig. 3. Drawing of a 9-year-old girl

Children's perception of family conflicts is manifested in the drawings by the following features: barriers between figures; drawing and subsequent erasure or strikethrough of figures; selection of individual figures; decrease / increase some figures in the drawing; absence of some family members; isolation of separate figures; the presence of things more than people; absence of body parts in some figures, etc. In conversations after drawing, children from such families behave in two ways: some take a cautious and conciliatory position ( «not to contradict»), others - oppositional or defensive-aggressive.

Favorable family situation and the child's feeling of acceptance in it are determined if the child's drawing is dominated by the following features: the image of all family members, the overall positive atmosphere of the drawing, smiles on their faces; absence of isolated, demonstratively selected figures; no hatching, dark colors, corrections, erasures or sketches of faces and details; adequate placement of figures on the sheet; confident drawing lines, without pressure; no image of family members with hostile, sad faces, sharp objects in their hands, etc. During the conversation, the child does not linger long when asked who is drawn, what they do, whether they are hap-

(C) Shyriaieva Liudmyla, Honcharenko Nataliia DOI (article): https://doi.org/10.32626/2227-6246.2020-50.328-351 
DOI: https://doi.org/10.32626/2227-6246.2020-50 2020. випуск 50

py or bored, etc., gives positive answers, considering herself / himself and others happy.

We give an example of Fig. 4 as an illustration, the author of which is an 8-year-old boy with ADHD of mostly inattentive subtype. School performance (intermediate level) is supported by the contribution of parents to help with homework, organized control over the activities of the child. The family is financially and psychologically prosperous. The composition of the family is completely reproduced in the drawing. The distance between the family members is explained by the boy that they play, throwing up and catching hats. The boy slowly became involved in both the communication and the tasks offered, showing the shyness that was confirmed by the mother during the interview.

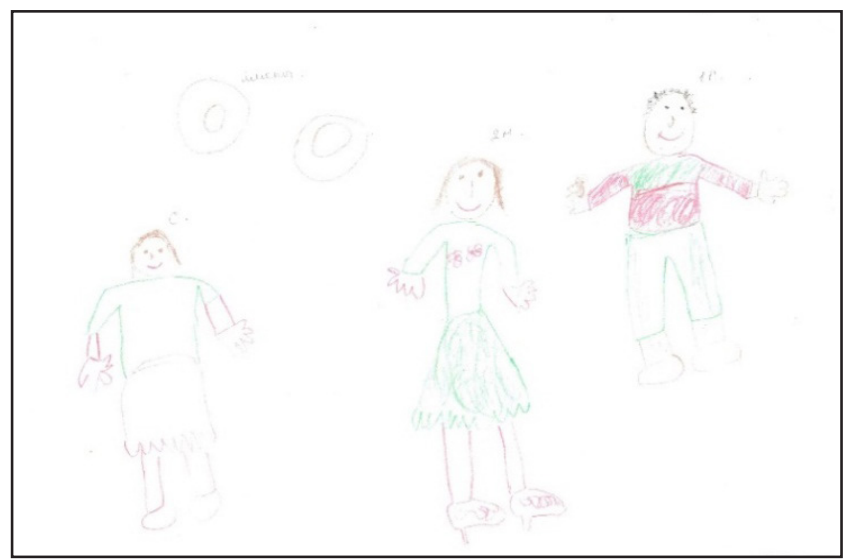

Fig. 4. Drawing of an 8-year-old boy

Qualitative and quantitative analysis of children's drawings and data from parental interviews revealed that «feelings of rejection" in the family are more common among children with ADHD than «feelings of acceptance» $(71.8 \%$ and $28.1 \%$, respectively). Disorders such as conflict, quarrels, child neglect, hypersocialization, hypercontrol, and so on are common (C) Shyriaieva Liudmyla, Honcharenko Nataliia

DOI (article): https://doi.org/10.32626/2227-6246.2020-50.328-351 
in children's families. As a psychological way of processing the «feeling of rejection», children are dominated by a symbolic «expulsion" from the family, rather than «expulsion of the family», which indicates a high need for intimacy, belonging, which are deprived. The image of only the author himself / herself in the task "to draw a family» was recorded by us only in $6.2 \%$ of cases in the sample ( «expulsion of the family»), but as "expulsion of oneself» from the family was a more common option $(21.8 \%)$.

\section{Conclusions}

Thus, the above formal, graphic and procedural characteristics of drawings are symbolic to determine the peculiarities of the perception of a child with ADHD interpersonal family relationships and his / her place in it. They allow us to identify the nature of satisfaction / dissatisfaction of the child's needs for love, security, acceptance, reflect certain aspects of well-being / unhappiness in family interpersonal relationships that affect the child's feelings.

Social factors, in particular the family situation, do not cause ADHD, but determine the further development of children with this disorder and the path of their fate in the future more significantly than for children without ADHD, because their adaptive resources are much lower.

The "Drawing of the family" is an effective tool for understanding the «image of the world» of a child with ADHD, and can be used effectively in the work of a psychologist in the construction of the future psychocorrectional hypotheses to determine the direction of psychological assistance to children and their parents.

A promising continuation of this study may be to test the possibility of using graphical features of the technique «Family Drawing" and other drawing techniques for the differential diagnosis of ADHD and the norm among primary school children. In particular, as markers of $\mathrm{ADHD}$ can be tested such

(C) Shyriaieva Liudmyla, Honcharenko Nataliia DOI (article): https://doi.org/10.32626/2227-6246.2020-50.328-351 
DOI: https://doi.org/10.32626/2227-6246.2020-50 2020. випуск 50

features as: speed of drawings, body distortion, its disproportion, the absence of body parts (characteristics of the drawing that do not correspond to age), strong hatching, line pressure, accentuated use of purple, violet, etc.

\section{Literature}

Беляускайте Р. Ф. Рисуночные пробы как средство диагностики развития личности ребенка. Психологическое обследование детей дошкольного и младшего школьного возраста: Тексты и летодические латериаль / ред.-сост. Г. В. Бурменская. Москва : УМК «Психология», 2003. С. 220-231. URL : http://psychlib.ru/inc/ absid.php?absid=179435.

Бодалев А. А., Столин В. В., Аванесов В. С. Общая психодиагностика. Санкт-Петербург : Речь, 2000. 440 с.

Брязгунов И. П., Касатикова Е. В. Непоседливый ребенок, или все о гиперактивных детях. Москва : Изд-во Института психотерапии, 2001. 96 c.

Венгер А. Л. Психологические рисуночные тесты: Иллюстрированное руководство. Москва : Изд-во «ВЛАДОС-ПРЕСС», 2003. 160 с.

Дилео Д. Детский рисунок. Диагностика и интерпретация. Москва : Изд-во Института психотерапии, 2012. 238 с.

Политика О. И. Дети с синдромом дефицита внимания и гиперактивностью. Санкт-Петербург : Речь, 2006. 208 с.

Романчук О. Гіперактивний розлад з дефіцитом уваги у дітей. Львів : Свічадо, 2015. 300 с.

Семакова Е. В., Макарова И. Ю. Семейно-социальные условия развития гиперактивности. Успехи совреленного естествознания. 2007. № 9. C. 23-26. URL : http://www.natural-sciences.ru/ru/article/ view?id=11467.

Серов Н. В. Символика цвета. Санкт-Петербург : Страта, 2019. 195 с.

Суковський Є. Г. Гіперактивний розлад з дефіцитом уваги у дітей: порадник для батьків. Львів : Колесо, 2008. 144 с.

Сухіна I. В. Гіперактивна дитина. Харків : Ранок; ВГ «Кенгуру», 2018. $40 \mathrm{c.}$

Федоренко М. В. Психодіагностика та психокорекція синдрому гіперактивності у дітей дошкільного віку з розумовою відсталістю: дис. ... канд. психол. наук: 19.00.08. Київ, 2015. 285 с.13.

Хоментаускас Г. Т. Отражение межличностных отношений в диагностическом рисунке семьи: автореф. дис. ... канд. псих. наук. 19.00.01. Москва, 1984. 24 с.

(C) Shyriaieva Liudmyla, Honcharenko Nataliia

DOI (article): https://doi.org/10.32626/2227-6246.2020-50.328-351 
Aili, H. H., Norharlina, B., Manveen, K. S., \& Wan Salwina, W. I. (2015). Family Difficulties in Children with ADHD, the Role of Integrated Psychopharmacology Psychotherapy Treatment. DOI 10.5772/61416. URL : https://www.intechopen.com/books/adhd-new-directions-indiagnosis-and-treatment/family-difficulties-in-children-withadhd-the-role-of-integrated-psychopharmacology-psychotherapy-tr.

Barkley, R. A. (2013). Taking Charge of ADHD, the Complete Authoritative Guide for Parents. New York : Guilford Press. 363 p.

Burns, R. C., \& Kaufman, S. H. (1972). Action, Styles, and Symbols in Kinetic Family Drawings (K-F-D). New York : Taylor \& Francis Group, LLC. 320 p.

Corman, L. (1964). The Family Drawing Test in Medical-Pedagogical Practice. Paris : P.U.F.

Godinez, D. A., Willcutt, E. G., Burgess, G. C., Depue, B. E., Andrews-Hanna, J. R., \& Banich, M. T. (2015). Familial risk and ADHD-specific neural activity revealed by a case-control, discordant twin pair design. Psychiatry Research. P. 458-465.

Johnston, C., \& Mash, E. J. (2001). Families of children with attention-deficit / hyperactivity disorder: Review and recommendations for future research. Clinical Child and Family Psychology Review. Vol. 4. P. 183-207.

Krisch, J. (2019). How to Draw Conclusions About What Children's Art Really Means. URL : https://www.fatherly.com/health-science/ kid-art-what-children-are-thinking.

Zhao, X., Page, T. F., Altszuler, A. R., Pelham, W. E., Kipp, H., Gnagy, E. M., ... \& Macphee, F. L. (2019). Family Burden of Raising a Child with ADHD. Journal of Abnormal Child Psychology, 1-12. DOI 10.1007/ s10802-019-00518-5.

\section{References}

Beliauskaite, R. F. (2003). Risunochnyie proby kak sredstvo diagnostiki razvitiia lichnosti rebenka [Drawing tests as a means of diagnosing the development of a child's personality]. Psikhologicheskoie obsledovaniie detei doshkolnogo i mladshego shkolnogo vozrasta - Psychological examination of children of preschool, primary school age. G. V. Burmenskaia (Ed.). Moskva : UMK «Psikhologiia». Retrieved from http://psychlib.ru/inc/absid.php?absid=179435 [in Russian].

Bodaliev, A. A., Stolin, V. V., \& Avanesov, V. S. (2000). Obshchaia psikhodiagnostika [General psychodiagnostics]. Sankt-Peterburg : Rech [in Russian].

(C) Shyriaieva Liudmyla, Honcharenko Nataliia DOI (article): https://doi.org/10.32626/2227-6246.2020-50.328-351 
Briazgunov, I. P., \& Kasatikova, E. V. (2001). Neposedlivyi rebenok, ili vse o giperaktivnykh detiakh [Restless child, or everything about hyperactive children]. Moskva : Izd-vo In-ta psikhoterapii [in Russian].

Venger, A. L. (2003). Psikhologicheskiie risunochnyie testy: Illiustrirovannoie rukovodstvo [Psychological Drawing Tests: An Illustrated Guide]. Moskva : VLADOS-PRESS [in Russian].

Dileo, D. (2012). Detskii risunok. Diagnostika i interpretatsiia [Children's drawing. Diagnosis and interpretation]. Moskva : Izd-vo Instituta psikhoterapii [in Russian].

Politika, O. I. (2006). Deti s sindromom defitsita vnimaniia i giperaktivnostiu [Children with attention deficit and hyperactivity disorder]. Sankt-Peterburg : Rech [in Russian].

Romanchuk, O. (2015). Hiperaktyvnyi rozlad $z$ defitsytom uvahy u ditei [Hyperactive breakdown with deficiency of attention in children]. Lviv : Svichado [in Ukrainian].

Semakova, E. V., \& Makarova, I. Yu. (2007). Semeino-sotsialnyie usloviia razvitiia giperaktivnosti [Family and social conditions for the development of hyperactivity]. Uspekhi sovremennogo estestvoznaniia - The successes of modern natural science, 9, 23-26. Retrieved from http://www.natural-sciences.ru/ru/article/view?id=11467 [in Russian].

Serov, N. V. (2019). Simvolika tsveta [Symbolics of colour]. Sankt-Peterburg : Strata [in Russian].

Sukovskyi, Ye. H. (2008). Hiperaktyvnyi rozlad $z$ defitsytom uvahy u ditei: poradnyk dlia batkiv [Hyperactive breakdown with a deficiency of attention among children: a guide for arents]. Lviv : Koleso [in Ukrainian].

Sukhina, I. V. (2018). Hiperaktyuna dytyna [Hyperactive child]. Kharkiv : Ranok; VH «Kenhuru» [in Ukrainian].

Fedorenko, M. V. (2015). Psykhodiahnostyka ta psykhokorektsiia syndromu hiperaktyvnosti u ditei doshkilnoho viku z rozumovoiu vidstalistiu [Psychodiagnostics and psychocorrection of hyperactivity syndrome among children of preschool age with mental retardation]. Candidate's thesis. Kyiv [in Ukrainian].

Khomentauskas, G. T. (1984). Otrazheniie mezhlichnostnykh otnoshenii v diagnosticheskom risunke semi [Reflection of interpersonal relations in the diagnostic drawing of the family]. Extended abstract of candidate's thesis. Moskva [in Russian].

Aili, H. H., Norharlina, B., Manveen, K. S., \& Wan Salwina, W. I. (2015). Family Difficulties in Children with ADHD, the Role of Integrated Psychopharmacology Psychotherapy Treatment. DOI 10.5772/61416.

(C) Shyriaieva Liudmyla, Honcharenko Nataliia

DOI (article): https://doi.org/10.32626/2227-6246.2020-50.328-351 
Retrieved from https://www.intechopen.com/books/adhd-newdirections-in-diagnosis-and-treatment/family-difficulties-inchildren-with-adhd-the-role-of-integrated-psychopharmacologypsychotherapy-tr.

Barkley, R. A. (2013). Taking Charge of ADHD, the Complete Authoritative Guide for Parents. New York : Guilford Press.

Burns, R. C., \& Kaufman, S. H. (1972). Action, Styles, and Symbols in Kinetic Family Drawings $(K-F-D)$. New York : Taylor \& Francis Group, LLC.

Corman, L. (1964). The Family Drawing Test in Medical-Pedagogical Practice. Paris : P.U.F.

Godinez, D. A., Willcutt, E. G., Burgess, G. C., Depue, B. E., Andrews-Hanna, J. R., \& Banich, M. T. (2015). Familial risk and ADHD-specific neural activity revealed by a case-control, discordant twin pair design. Psychiatry Research, 233, 458-465.

Johnston, C., \& Mash, E. J. (2001). Families of children with attention-deficit / hyperactivity disorder: Review and recommendations for future research. Clinical Child and Family Psychology Review, 4, 183-207.

Krisch, J. (2019). How to Draw Conclusions About What Children's Art Really Means. Retrieved from https://www.fatherly.com/healthscience/kid-art-what-children-are-thinking.

Zhao, X., Page, T. F., Altszuler, A. R., Pelham, W. E., Kipp, H., Gnagy, E. M., ... \& Macphee, F. L. (2019). Family Burden of Raising a Child with ADHD. Journal of Abnormal Child Psychology, 1-12. DOI 10.1007/ s10802-019-00518-5.

Ширяєва Людмила, Гончаренко Наталія. Особливості сприйняття сімейних взаємостосунків і свого місия в сім'ї дитиною із синдромом дефіциту уваги та гіперактивності

\section{АНОТАЦІЯ}

Метою статmі $\epsilon$ висвітлення результатів проведеного серед дітей молодшого шкільного віку із синдромом дефіциту уваги та гіперактивністю дослідження особливостей сприйняття ними сімейних взаємостосунків і свого місия в сім'ї.

Методи. Для досягнення поставленої мети та реалізації завдань використано проективну методику "Малюнок сім'ї». У якості критеріїв оцінки малюнків проаналізовано: 1) формальну структуру малюнка; 2) графрічну презентацію членів сім'ї; 3) прочес малювання. Вибірку

(C) Shyriaieva Liudmyla, Honcharenko Nataliia DOI (article): https://doi.org/10.32626/2227-6246.2020-50.328-351 
DOI: https://doi.org/10.32626/2227-6246.2020-50 2020. випуск 50

дослідження склали діти 6-10 років і їх батьки загальною кількістю 128 осіб: 64 дитини та 64 дорослих. Із батьками проведено структуроване інтерв'ю.

Результати дослідження. Установлено, що у сприйнятті сімейної ситуації та свого місця у сім'ї дітьми із СДУГ простежуються такі загальні тенденції, як тривожність, почуття неповноцінності, пригніченості, негативне або боязке ставлення до одного з батьків, негативне ставлення до сіблінгів. У сім'ях дітей із СДУГ виявлено поширеність таких видів неблагополуччя, як: сварки між батьками, конфрлікти між батьками (або одним із них) і дитиною із СДУГ, між нею та сіблінгами, ігнорування дитини, гіперсоціалізація дитини, гіперконтроль тощо.

Проаналізовано кількісно та якісно (з ілюстрацією прикладів) графічні характеристики малюнка, що мають символічне значення для визначення задоволення / незадоволення потреб дитини. Показано, що малюнок відображає два вектори переживання дитиною свого місия в сім'ї: «прийняття» та «відторгнення». Більш розповсюдженим виявлено почуття дитиною "відторгнення» у сім'ї, на відміну від почуття «прийняття» (71,8\% і 28,1\% відповідно). У якості способу «переробки» почуття “відторгнення» діти віддають перевагу “виганяти себе», а не сім'ю, що свідчить про депривацію потреб у близькості, приналежності.

Висновки. Малюнки сім'ї можуть використовуватися у діагностиці дітей із СДУГ для побудови наступних психокорекційних гіпотез з метою реалізації ефективної психологічної допомоги дитині та сім'ї загалом.

Ключові слова: сім'я, міжособистісні стосунки у сім'ї, СДУГ (синдром дефіциту уваги та гіперактивності), проективні методики, методика «Малюнок сім'ї», почуття приналежності, почуття відторгнення.

Ширяева Людмила, Гончаренко Наталья. Особенности восприятия семейных взаимоотношений и своего места в семье ребенком с синдромом дефицита внимания и гиперактивности

\section{АННОТАЦИЯ}

Целью статьи является освещение результатов исследования особенностей восприятия семейных взаимоотношений и своего места в семье детьми младшего школьного возраста с синдромом дефицита внимания и гиперактивностью.

C Shyriaieva Liudmyla, Honcharenko Nataliia

DOI (article): https://doi.org/10.32626/2227-6246.2020-50.328-351 
DOI: https://doi.org/10.32626/2227-6246.2020-50 2020. випуск 50

Методы. Для достижения поставленной цели и реализации задач использована проективная методика «Рисунок семьи». В качестве критериев оценки рисунков проанализированы: 1) формальная структура рисунка; 2) графическая презентацию членов семьи; 3) процесс рисования. Выборку исследования составили дети 6-10 лет и их родители общим количеством 128 человек: 64 ребенка и 64 родителя. С родителями проведено структурированное интервью.

Результаты исследования. Установлено, что в восприятии семейной ситуации и своего места в семье детьми с СДВГ прослеживаются такие общие тенденции, как тревожность, чувство неполноценности, подавленности, отрицательное или боязливое отношение к одному из родителей, негативное отношение к сиблингам. В семьях детей с СДВГ выявлена распространенность таких видов неблагополучия, как: ссоры между родителями, конфлликты между родителями и ребенком с СДВГ, между ребенком и сиблингами, игнорирование ребенка, гиперсоциализачия, гиперконтроль и т. п.

Количественно и качественно (с иллюстрацией примеров) проанализированы графические характеристики рисунка, которые имеют символическое значение для определения удовлетворения / неудовлетворения потребностей ребенка. Показано, что рисунок отражает два вектора переживания ребенком своего места в семье: «принятие» и "отвержение». Более распространенным выявлено чувство "отвержения» ребенка с СДВГ в семье, нежели чувство «принятия» $(71,8 \%$ и $28,1 \%$ соответственно). В качестве психологического способа "переработки» чувства "отвержения» дети предпочитают «изгонять» себя из семьи, а не семью, что свидетельствует о депривации их потребностей в близости, принадлежности.

Выводы. Рисунки семьи могут использоваться в диагностике детей с СДВГ для построения психокоррекционных гипотез с целью реализации эффрективной психологической помощи ребенку и семье в целом.

Ключевые слова: семья, межличностные отношения в семье, СДВГ (синдром дефицита внимания и гиперактивности), проективные методики, методика "Рисунок семьи», чувство принадлежности, чувство отверженности.

Original manuscript received June 02, 2020

Revised manuscript accepted July 17, 2020

(C) Shyriaieva Liudmyla, Honcharenko Nataliia DOI (article): https://doi.org/10.32626/2227-6246.2020-50.328-351 